\title{
Biotic recovery after the end-Triassic extinction event: Evidence from marine bivalves of the Neuquén Basin, Argentina
}

\author{
Susana E. Damborenea*, Javier Echevarría, Sonia Ros-Franch \\ Museo de Ciencias Naturales La Plata, Paseo del Bosque s/n, 1900 La Plata, Argentina \\ Consejo Nacional de Investigaciones Científicas y Técnicas (CONICET), Argentina.
}

\section{A R T I C L E I N F O}

\section{Keywords:}

Triassic/Jurassic crisis

Rhaetian

Hettangian

Sinemurian

Marine benthonic diversity

South America

Diversity dynamics

\begin{abstract}
A B S T R A C T
We analyze the Late Triassic extinction and Early Jurassic recovery of bivalve faunas within marine environments in the Atuel River area of the Neuquén Basin, Argentina. Data were collected from a hundred samples with invertebrates in a well-exposed uppermost Triassic to lower Jurassic section in the Neuquén Basin (southern Mendoza Province, Argentina) and allow a high-resolution reconstruction of the local diversity dynamics. The nearly continuous presence of marine stenohaline major taxa such as cnidarians, rhynchonelliform brachiopods, echinoderms and cephalopods indicates normal salinity throughout. All bivalve species were identified, and each occurrence was recorded in meters above the base. To analyze the systematic diversity trends, diversity curves were calculated on the basis of the first and last occurrence data for each bivalve species, and both total diversity and boundary crossers diversity were used. As a result, four main phases were identified: a) Triassic equilibrium phase (Rhaetian), with relatively high origination and extinction rates; b) extinction phase (latest Rhaetian to earliest Hettangian), with high extinction rates and low origination rates; c) recovery phase (late Early to early Late Hettangian), with high origination rates and almost null extinction rates; and d) Jurassic equilibrium phase (Late Hettangian-Sinemurian), again with similar and relatively high origination and extinction rates. The extinction and recovery phases are separated by a gap of about $135 \mathrm{~m}$ without identifiable benthonic invertebrates but with early Hettangian ammonites. On the other hand, bivalve palaeoecologic diversity seems to have been more homogeneous along the section, being dominated by attached epifaunal species, though before the extinction epifaunal habits were slightly surpassed by infaunal ones. Slight differences observed include a) shallow burrowers were more diverse during the Rhaetian than during the earliest Jurassic and b) epifaunal free-lying and semi-infaunal attached bivalves were more diverse after the Rhaetian extinction.
\end{abstract}

\section{Introduction}

The end-Triassic ( $\mathrm{Tr} / \mathrm{J})$ extinction event is one of the "big five" global crises in the history of life in the marine realm (Raup and Sepkoski, 1982), with a total loss of about $22 \%$ of families and a generic loss estimated by different authors between 33\% and 73\% (Jablonski, 1994; Benton, 1995; Bambach et al., 2004; McGhee et al., 2004, 2013). The extinction was, according to some authors, equally or more severe than the end-Cretaceous crisis, with a calculated species loss (based on rarefaction techniques) of about 80\% (Raup and Sepkoski, 1988; Jablonski, 1994). Several studies suggest that the ecologic effect of this extinction on the global biosphere was more significant than the magnitude of taxonomic diversity loss would suggest (McGhee et al., 2004, 2013; Mander et al., 2008; Ros, 2009; Ros and Echevarría, 2011, 2012; Ros et al., 2011).

Paradoxically, the end-Triassic extinction and the subsequent biotic recovery are not so well known as others (Hallam and Wignall, 1997, p. 142; Wignall and Bond, 2008), or at least did not attract the same amount of attention (Twitchett, 2006), probably due to the fact that there are few adequate fossiliferous sections worldwide. As a result, most of the published analyses were based on data from the Northern Hemisphere: Europe (Johnson and Simms, 1989; Allasinaz, 1992; Warrington et al., 1994; McRoberts and Newton, 1995; McRoberts et al., 1995; Kiessling et al., 2007; Wignall and Bond, 2008; Mander and Twitchett, 2008; Mander et al., 2008; Clémence et al., 2010), Tibet (Hautmann et al., 2008) and the North American Cordillera (Tanner et al., 2004; Guex et al., 2004; Wignall et al., 2007). This limited picture will be surely enriched (and may even change) as Southern Hemisphere information becomes better known; for instance, sections in the Peruvian Andes have provided good data to quantitatively analyze ammonoid post-extinction recovery and diversification (Guex et al., 2012).

When quantified, the known results are diverse: the recovery period

\footnotetext{
* Corresponding author.

E-mail address: sdambore@fcnym.unlp.edu.ar (S.E. Damborenea).
} 
after the end-Triassic extinction was inferred to be long for reef communities (up to between 5 and 10 million years, see Cooper, 1989; Lathuilière and Marchal, 2009; Kiessling, 2010), relatively faster for other benthonic faunas (Hallam, 1987, 1996; Wignall and Bond, 2008), but not necessarily geographically homogeneous (Raup and Jablonski, 1993; Jablonski, 1994), and may have been nearly "instantaneous" locally (Hautmann et al., 2008). For ammonites the diversification was fast, likely less than 100 kyr after the extinction (Guex et al., 2012).

Bivalves are one of the best studied groups in relation to the recovery after the end-Triassic extinction event. This is due to their abundance and diversity in different marine and marginal marine habitats, and also to the fact that they are relatively well-known. It was even suggested that bivalves may "serve as a proxy for marine invertebrate biodiversity changes as a whole" (McRoberts et al., 1995). Bivalves provided the material of several studies in this context, mainly focused on the extinction itself and on European comprehensive data bases (Hallam, 1981; Hallam and Miller, 1988; Allasinaz, 1992; McRoberts and Newton, 1995; McRoberts et al., 1995; Wignall and Bond, 2008; Mander et al., 2008), or on global comprehensive data (Hallam, 1981; Ros, 2009; Ros and Echevarría, 2011, 2012). Likewise, most of what is known about the characteristics of the biotic recovery phase or rebuilding of the marine ecosystem after the extinction event is also based upon European bivalve data (McRoberts and Newton, 1995; Hallam, 1996; Mander et al., 2008). Still, more geographically explicit data are needed to understand the spatial fabric of extinctions and recoveries (Jablonski, 2005; Valentine et al., 2008).

The general purpose of this paper is to analyze the response of bivalves to the end-Triassic extinction event in an exceptionally wellexposed uppermost Triassic-lowermost Jurassic section of the Andes at a very well-known South American region, the Neuquén Basin in western Argentina. Three specific aims were targeted to characterize that response: 1) recognition of the diversity patterns by means of diversity curves and evolutionary rates; 2) recognition of the ecologic patterns comparing the main ecologic bivalve habits; and 3) recognition of the systematic/biogeographic patterns considering the time and region of appearance worldwide of the taxa recorded in the basin.

South American Upper Triassic-Lower Jurassic bivalve faunas were the subject of recent revisions and ongoing taxonomic research (Damborenea, 1987a, 1987b, 1993, 1998, 2002, 2004; Aberhan, 1994, 2004; Damborenea and Lanés, 2007; Pérez et al., 2008; Damborenea and Manceñido, 2012). This paper is based on data collected over the years in a key area of the Neuquén Basin where the Triassic-Jurassic transition is documented in a fully marine succession (Riccardi et al., 1997a, 1997b, 2004; Lanés, 2005). Though this analysis covers the extinction and provides some comparisons for the Triassic data, it is mostly focused on the recovery, for which enough robust data are available. The extinction event itself is poorly known in this particular area, and the scarce data are not adequate to meaningfully recognize detailed timing and pattern. We analyze the Rhaetian-Sinemurian time interval in the area of the upper Atuel River in Mendoza Province (Argentina) with the purpose to characterize and time the recovery and understand its relationships to environmental changes, as a contribution to discriminate between regional and global conditions in the post $\mathrm{Tr} / \mathrm{J}$ recovery issue. This new set of local data can be compared with information from other latitudes and contribute to future global analyses.

\section{Late Triassic-Earliest Jurassic faunas in South America}

Uppermost Triassic - lowermost Jurassic sediments are known from several locations along western South America, but good continuous sections through marine sediments are few and many are still poorly known (see discussion in Riccardi et al., 2004; Damborenea et al., 2009). Nevertheless, when studied in detail some of them have proven to be exceptionally good, and are providing key palaeontologic data to understand the faunal turnover at the $\mathrm{Tr} / \mathrm{J}$ boundary (i.e., Schaltegger et al., 2008; Guex et al., 2012).

Upper Triassic marine faunas were mentioned from Colombia (Geyer, 1973), and are known from several localities in Perú (Jaworski, 1922; Körner, 1937; Steinmann, 1929; Cox, 1949; Nicol and Allen, 1953; Boit, 1966; Rangel, 1978; Maeda et al., 1983; Stanley, 1994; Hillebrandt, 1994), and Chile (Fuenzalida Villegas, 1937; Barthel, 1958; Thiele-Cartagena, 1967; Cecioni and Westermann, 1968; Westermann, 1970; Hayami et al., 1977; Gutiérrez, 1979; Escobar, 1980; Moscoso and Covacevich, 1982; Chong and Hillebrandt, 1985; Fang et al., 1998; Rubilar, 1998; Pérez-Barría, 2004a, 2004b, 2005; Nielsen, 2005). In Argentina marine Triassic-lowermost Jurassic deposits were only relatively recently found in the Atuel River area (Riccardi et al., 1988, 1991, 1997a, 1997b, 2004; Riccardi and Iglesia Llanos, 1999; Damborenea and Manceñido, 2012). References from Bolivia (Beltan et al., 1987; Suárez-Riglos and Dalenz-Farjat, 1993) need revision, since the alleged Norian age of the Vitiacua Formation has been challenged (Sempere et al., 1992).

Lowermost Jurassic (Hettangian-early Sinemurian) marine faunas, with emphasis on ammonites, were described or illustrated from Colombia (Geyer, 1973), Perú (Tilmann, 1917; Geyer, 1979; Prinz, 1985; Prinz and Hillebrandt, 1994; Hillebrandt, 1994; Guex et al., 2004; Schaltegger et al., 2008), Chile (Quinzio, 1987; Covacevich et al., 1991; Aberhan, 1994, 2004; Hillebrandt, 2000b; Pérez et al., 2008) and Argentina (Riccardi et al., 1988, 2004; Damborenea, 2002). A regional biostratigraphic frame based on ammonites is available (Hillebrandt, 2000a, 2000b; Riccardi, 2008a, 2008b).

\section{Geologic setting}

The Neuquén Basin is a back-arc basin of extensional origin developed in the western convergent margin of the South American Plate. Though the marine basin later extended to western San Juan and Neuquén Provinces, marine sediments of Late Triassic-Earliest Jurassic age are limited to one of its northern depocenters in southern Mendoza (see Riccardi et al., 1988, 1991, 1997a), known as the Atuel/Valenciana half-graben (Manceda and Figueroa, 1993) or Atuel depocenter (Fig. 1, Fig. 2).

These deposits have been intensively studied from several points of view: sedimentology and lithofacies (Lanés, 2005), biofacies (Damborenea and Manceñido, 2005), tectosedimentary evolution (Lanés et al., 2008; Giambiagi et al., 2008), and petrofacies (Tunik et al., 2008), and are well-dated by ammonites (Riccardi et al., 1988, 1991, 1997a, 1997b, 2004; Riccardi and Iglesia Llanos, 1999).

The lithostratigraphic framework used here was established by Riccardi et al. (1997a); we follow Lanés (2005, and Lanés et al., 2008) on the depositional systems and environmental interpretation; and the local biostratigraphy is according to Riccardi (2008a, 2008b); Fig. 3). All deposits studied here belong to a synrift phase, and were interpreted as deposited in a fandeltaic environment within a marine basin and below wave base, according to the stenohaline fossils and the absence of wave structures (Lanés, 2005).

The Arroyo Malo Formation (Riccardi et al., 1997a) crops out in the Arroyo Malo halfgraben (Giambiagi et al., 2008) in the core of an anticline at Arroyo Alumbre, a northern tributary of Arroyo Malo (Fig. 2), and it comprises the lower $286 \mathrm{~m}$ of marine sediments in our logged section (Fig. 4). At its type-locality the base does not crop out, and this unit comprises sediments of late Triassic to early Hettangian age. Lanés et al. (2008) recognized a facial stacking pattern including five facies, with plane-laminated mudstone deposits and low-density turbidites at the base, followed by high and low-density turbidites, slump-derived cohesive debris flows and sedimentary deformation, and ending with channeled hyperconcentrated flow deposits, high and low density turbidites, and traction current deposits in lenses alternating with tabular beds of intraformational breccia and massive mud-supported conglomerates. There is an upwards increasing trend of debris flow, hyperconcentrated flow, and traction current deposits, and an upwards 

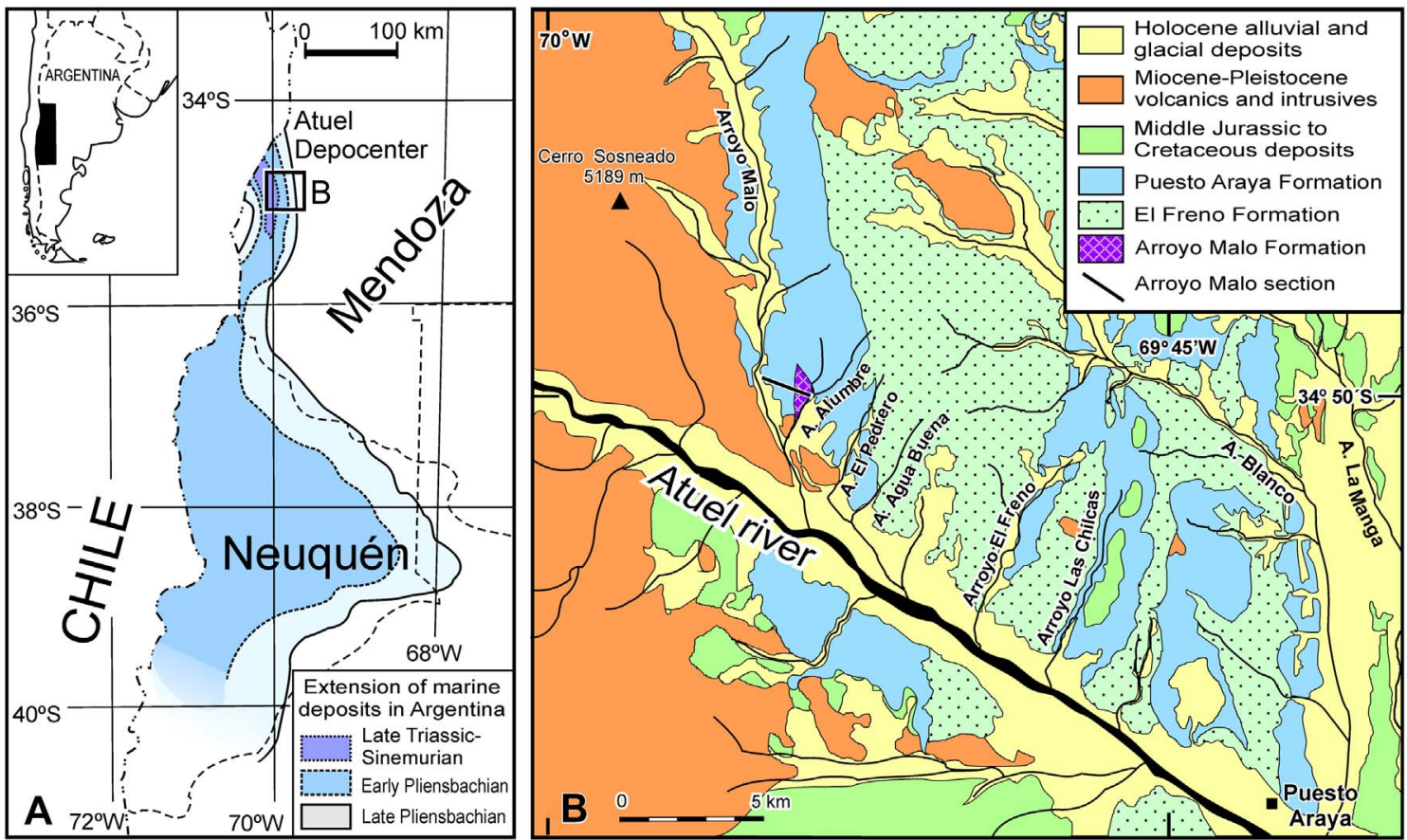

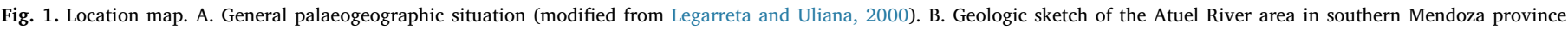
(simplified from Giambiagi et al., 2008), with location of main measured section at Arroyo Alumbre/Malo.
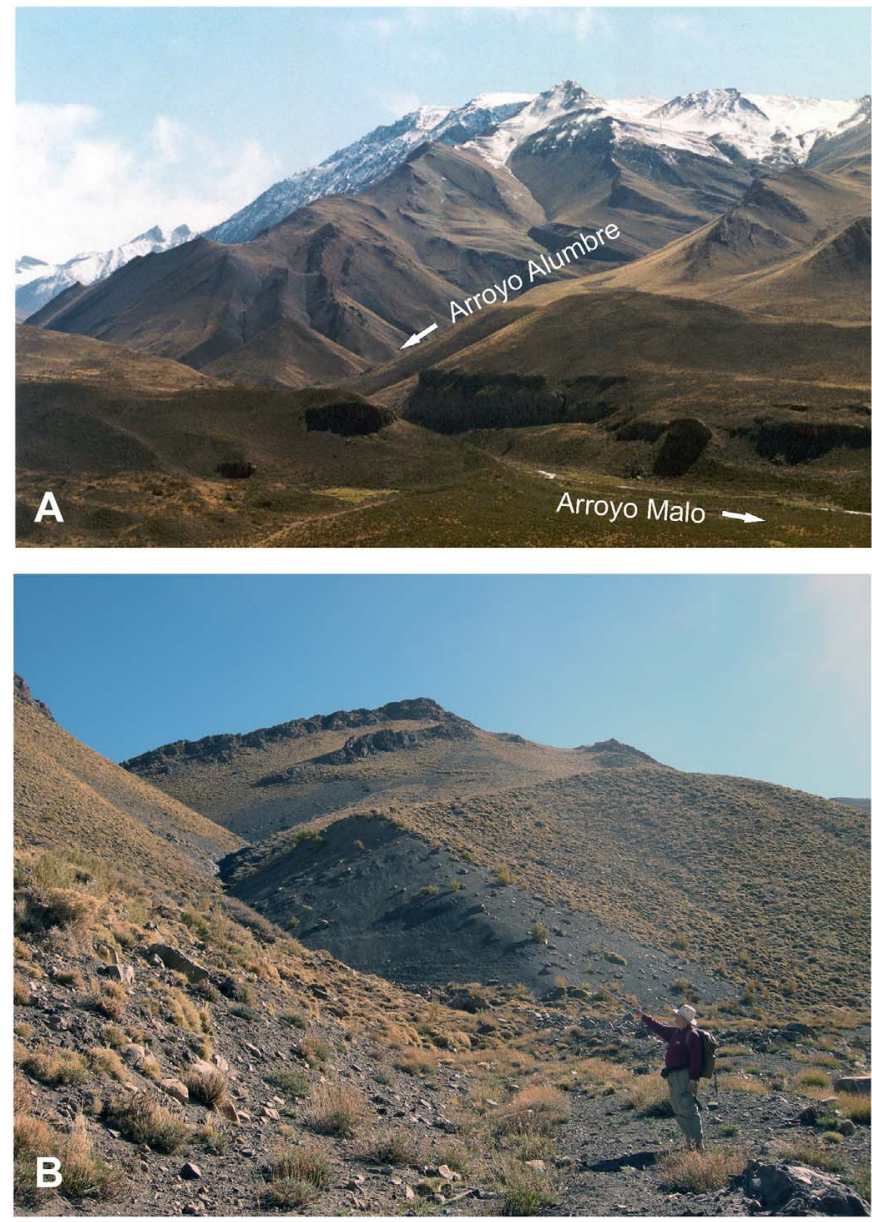

Fig. 2. A: General view of the Arroyo Alumbre/Malo section from the south, late Triassic sediments crop out at the anticlinal nucleus at the photograph center. B: Base of the measured section and outcrops of the Arroyo Malo Formation seen from Arroyo Alumbre. widening of lenses and trough-cross bedded sandstones (Lanés, 2005). Deposits of the Arroyo Malo Formation were interpreted as ranging in palaeoenvironment from basin area far from the delta front to slopetype fan delta upper front below wave base (Lanés et al., 2008). The last 30-40 m deposits are large lenses of pebbly sandstones and clast-supported conglomerates which were either referred to the El Freno Formation (Riccardi et al., 1997a; Lanés, 2005) or to the top of the Arroyo Malo Formation (Lanés et al., 2008; Echevarría et al., 2017; here). The Triassic/Jurassic boundary occurs within the Arroyo Malo Formation, in the transicional lithofacies sequence T2-T3-T4 (Lanés, 2005), or D2D3-D4 (Lanés et al., 2008), i.e. low- and high-density turbidity currents and mud deposition in a slope-type fan delta prodelta to delta front.

The upper $600 \mathrm{~m}$ of the logged section are referred to the lower section of the Puesto Araya Formation. Facies associations include wellbedded coarsening and thickening upwards low and high-density turbiditic sections, with usual slump folds, alternating with plane laminated mudstones, intraformational breccias and sandstones, and massive pebbly mudstones (Lanés et al., 2008). The Arroyo Alumbre/Malo section ends with tabular beds of tangential cross-bedded sandstones cut by channeled through-cross bedded sandstones interpreted as mouth bars cut by distributary channels (Lanés, 2005).

\section{Material and methods}

\subsection{Database}

The database here analyzed was built up after more than 30 years of sampling along the Arroyo Malo section, resulting in a high sample intensity and homogeneity across the logged section. One hundred samples with invertebrates were gathered from the Rhaetian-early Sinemurian interval (comprising more than $800 \mathrm{~m}$ thickness) at two measured sections at Arroyo Alumbre and from other isolated localities of the Atuel River region, southern Mendoza Province, Neuquén Basin (Fig. 1). Sections were measured by Riccardi et al. (1988, 1991, 1997a, 1997b, 2004, see also Damborenea, 2002, Damborenea and Manceñido, 2012). Some of the specimens were collected from the same sections by Silvia Lanés, who analyzed in detail the sedimentology (Lanés, 2005; Lanés et al., 2008). 


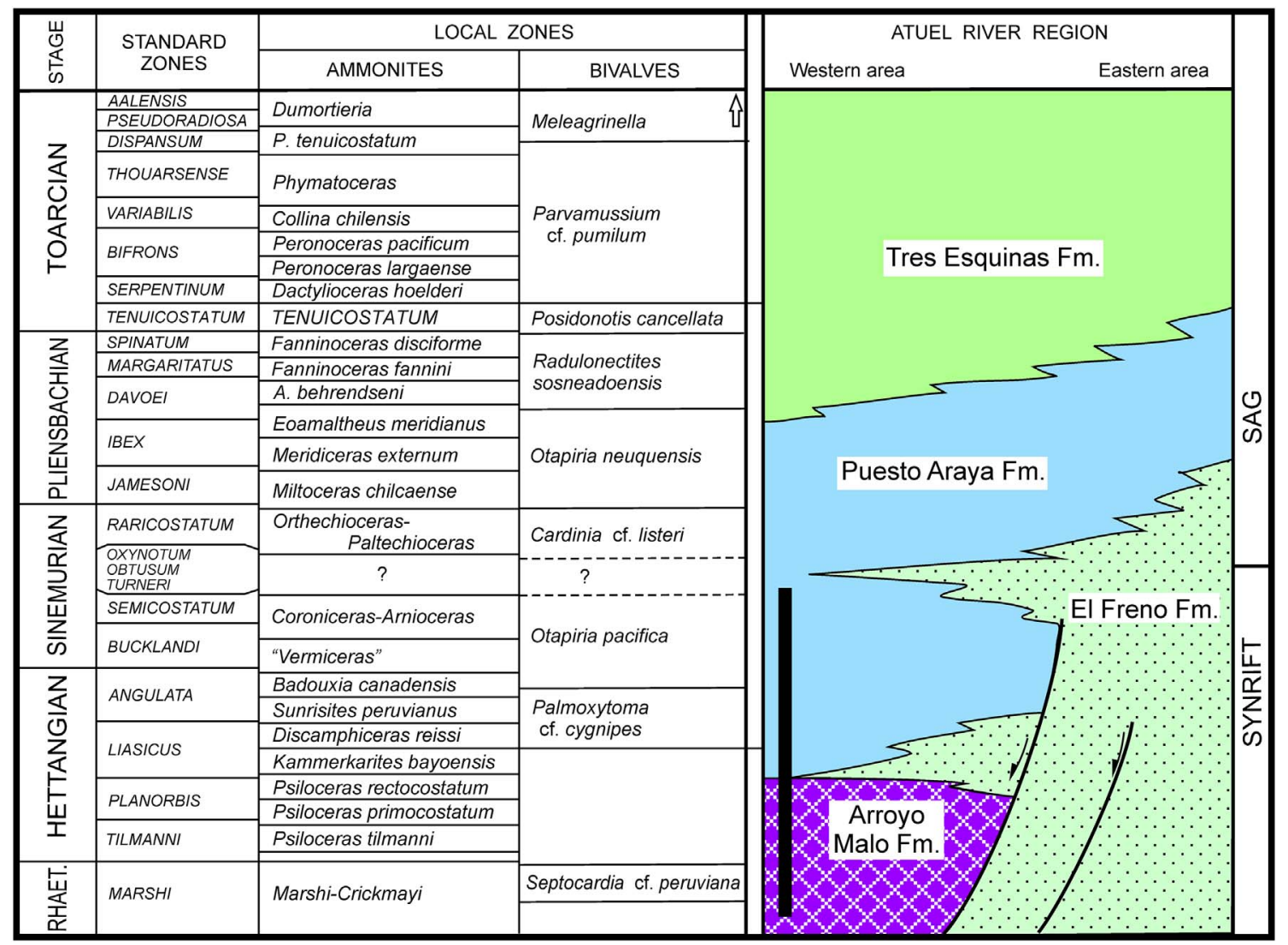

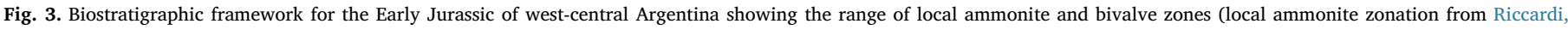

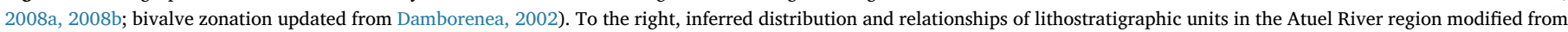
Lanés et al. (2008). Black bar shows extent of Arroyo Alumbre/Malo logged section.

All bivalve taxa were identified at the species level by one of us (SED), and to avoid distortions due to differences in scope in species concept only data from own or personally studied collections were used for this analysis. The upper Triassic fauna was recently systematically reviewed (Damborenea and Manceñido, 2012); on the other hand, most of the Hettangian/Sinemurian bivalves are still awaiting systematic revision, and thus many of the recognized species are named using open nomenclature. Specimens related to this study are housed in the invertebrate palaeontology collections of the La Plata Natural Sciences Museum (MLP).

To perform the ecologic analyses all recognized species were assigned to one of five available categories (see Stanley, 1970 for a discussion of the main functional morphological features): epifaunal attached (EA); epifaunal free-lying (EF); semi-infaunal attached (SIA); infaunal shallow burrower (ISB); and infaunal deep burrower (IDB). Epifaunal attached bivalves were mostly epibyssate, with only one species fully cemented (Liostrea sp.) and one cemented only during juvenile stages (Gryphaea sp.), which was assigned to the free-lying category. When required, especially to compare with other basins, cemented $[\mathrm{EA}(\mathrm{C})]$ and epibyssate $[\mathrm{EA}(\mathrm{B})]$ taxa were discriminated. Among shallow burrowers only one detritus feeding species (Palaeoneilo cf. elliptica) was identified, hence they were all grouped together in the category ISB, discriminating when necessary between ISB(S) for suspension feeders and ISB(D) for detritus feeders.

The location of samples containing bivalve specimens and the actual occurrence of each species in the section recorded in meters above the base of a combined section are shown on Fig. 4. Whenever possible, samples were dated according to ammonite occurrences. The relative abundance of taxa was not systematically recorded and thus only presence/absence data are used for this first analysis.

As a result most biases can be considered minimized: a) although sampling was not "controlled" in a strict sense, sampling intensity was uniform across the section, i.e. approximately the same time and attention was given to every fossiliferous level; b) within the section the main marine biofacies recognized by Damborenea and Manceñido (2005) are well represented, so facies control on the data can be assessed; and c) environmental conditions at the time of deposition were determined using Lanés' detailed sedimentary analysis of the same sections (Lanés, 2005; Lanés et al., 2008).

The main bias to take into account during the analysis is the edge effect, i.e., the apparent declination of diversity as we approach to the edges of analyzed strata due to incompleteness of the fossil record (Raup, 1972; Foote, 2000). The Signor-Lipps effect, i.e., the smooth drop of recorded diversity due to random truncation of ranges when approaching to a mass extinction event (Signor and Lipps, 1982; Raup, 1986), can be included within the wider spectrum of edge effects. This is notorious for the Triassic, since it is a minor proportion of the section extension (about 22\%) and is bounded by the base of the section and by the mass extinction at its top. Although the range of the species known to be present in the basin on subsequent stages was extended, there is a regional hiatus in the fossil record affecting the top of the section, so an increase on extinction levels and a reduction on apparent diversity are also expected at this point due to the edge effect.

\subsection{Analytic methods}

A diversity curve was constructed considering the first and last occurrence data for each species (FOD and LOD respectively); for the species known to be present in the basin afterwards, the LOD in the section was not considered. Floated ex-situ material was only taken into account when its stratigraphic provenance could be narrowed to short intervals. It was not considered when building the general diversity 


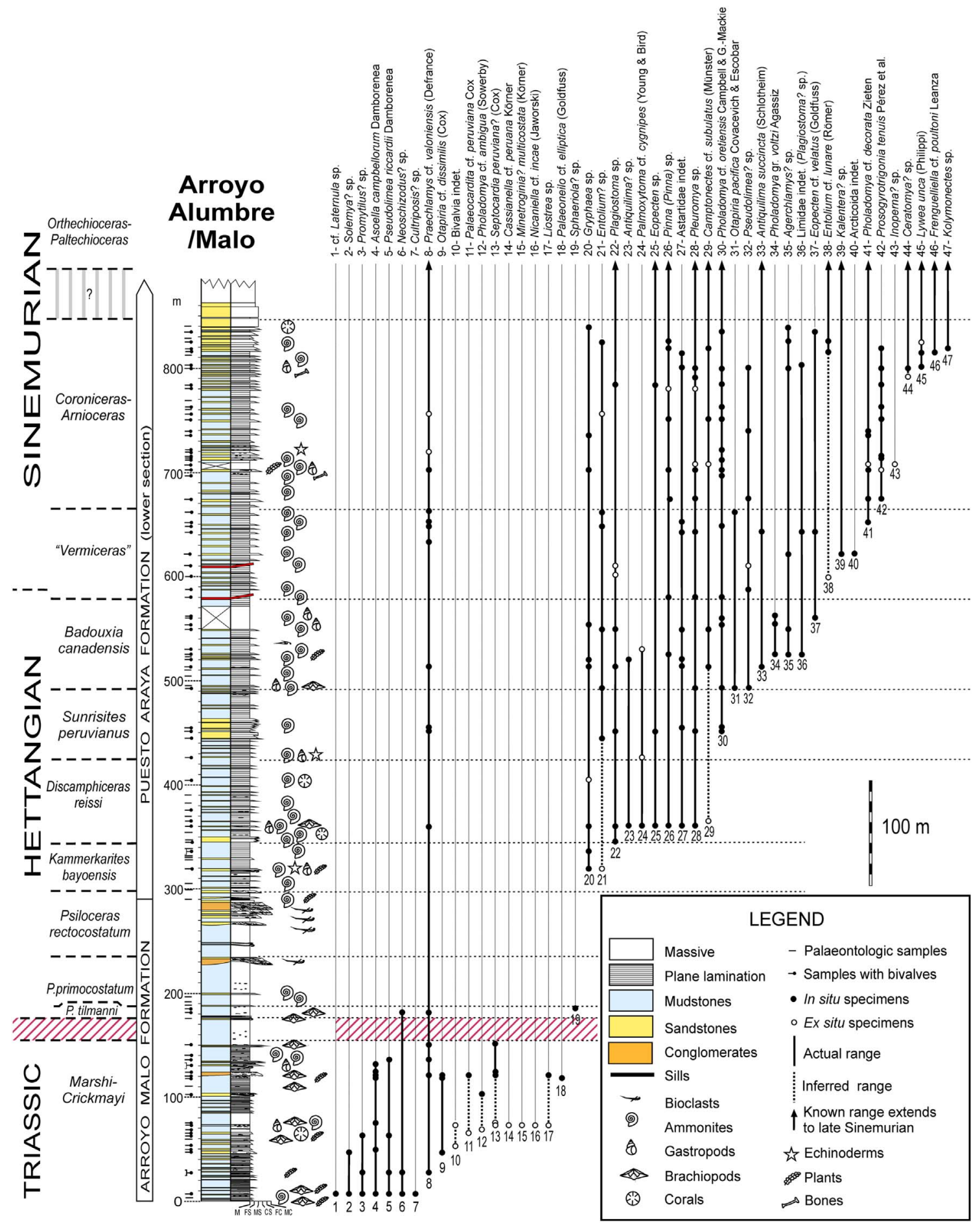

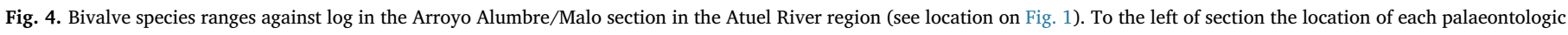

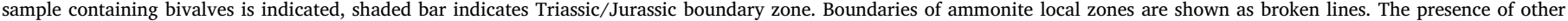
macroinvertebrate groups is indicated to the right of the section.

curve, but it was used during the ecologic analysis and to examine the faunal composition of the gross time bins analyzed (Triassic, Jurassic recovery, Jurassic equilibrium). As a consequence, overall diversity will be underestimated in the general diversity curve (especially for the Triassic), but its main changes will be better represented. The degree of resolution used is one meter (e.g., samples collected at 182.1 and $182.4 \mathrm{~m}$ were considered as a single sample at $182 \mathrm{~m}$ ). As a consequence, despite being a continuous section, the analyses can be perceived as performed on one meter bins.
Preservation potential across the section seems to be roughly homogeneous. A mean of 2.31 identified species per sample could be recognized in Triassic strata, while a mean of 2.95 identified species per sample were recovered from Jurassic strata. When compared to relative extension within the section these data result in 0.20 identifications per meter for the Triassic and 0.18 identifications per meter for the Jurassic. The term identification refers here to species identified in a sample, so if a species was identified in two samples, it will be counted twice. This suggests that the lower diversity seen in the Triassic is 
simply the consequence of having less thickness to study. When the exsitu material is included, this difference in diversity strongly decreases.

Two diversity metrics were used: total diversity (TD), i.e., for each sample: all species actually present in the sample plus those species present lower and higher in the section, though not in the sample; and boundary crossers (BC) at the top of the sample-bin, i.e., all species present before and after the top of the sample-bin (Foote, 2000). This last measurement avoids singletons (i.e., species present in a single sample), which may represent mostly taphonomic biases or extremely rare species, especially considering that this is the analysis of only one section.

In order to analyze instantaneous rates of origination and extinction, the number of FODs and LODs where divided by BC measure from the bottom boundary (i.e., the number of species entering the bin). Since BC measure avoids singletons, these were not counted among the FODs and LODs. The results obtained by this method correspond very well with those obtained using the estimated per-capita rates (Foote, 2000), but can be more readily interpreted. It must also be pointed out that these rates will represent local origination rates (i.e., covering origination and immigration) and local extinction rates (i.e., the species might be found in other basins afterwards).

To check for general trends in origination and extinction, cumulative FODs and LODs were compared to meters from the base, this time considering also singletons. When doing this comparisons regression lines where calculated, by ordinary least squares between FOD/LOD and section thickness. The slope of the regression lines of FODs and LODs against thickness will represent the number of species originating or going extinct per meter during the interval considered.

Based on the sediment thickness for the Hettangian, the only complete stage within the section, an average sedimentation rate (ASR) can be calculated. According to the International Commission of Stratigraphy (2017) time scale, the Hettangian lasted $2 \mathrm{Myr}$, and in the $\log$ section is represented by about $400 \mathrm{~m}$. This results in an ASR of $0.2 \mathrm{~m} / \mathrm{kyr}$, or one meter of sediment every 5000 years. This value was used to estimate origination and extinction rates relative to time.

\section{Results}

\subsection{Systematic diversity trends}

Fig. 5 shows the diversity curve for both metrics (TD and BC). The lower diversity shown by the Triassic strata is most probably caused by

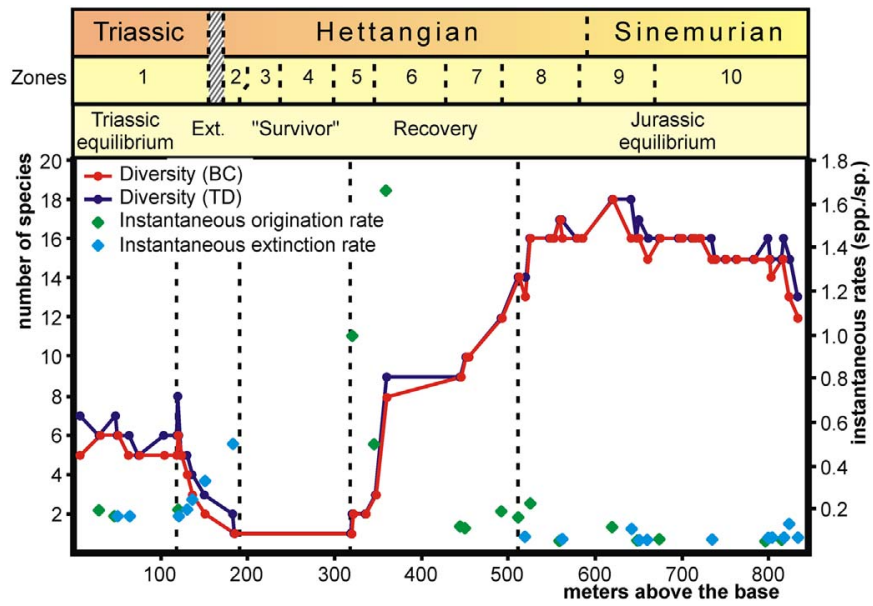

Fig. 5. Total diversity against section thickness. (TD) and boundary crossers (BC) along the section. Origination/migration rate and local extinction rate are also shown. Key to biozones: (1) Marshi-Crickmayi; (2) Psiloceras tilmanni; (3) Psiloceras primocostatum; (4) Psiloceras rectocostatum; (5) Kammerkarites bayoensis; (6) Discamphiceras reissi; (7) Sunrisites peruvianus; (8) Badouxia canadensis; (9) "Vermiceras"; (10) CoronicerasArnioceras.

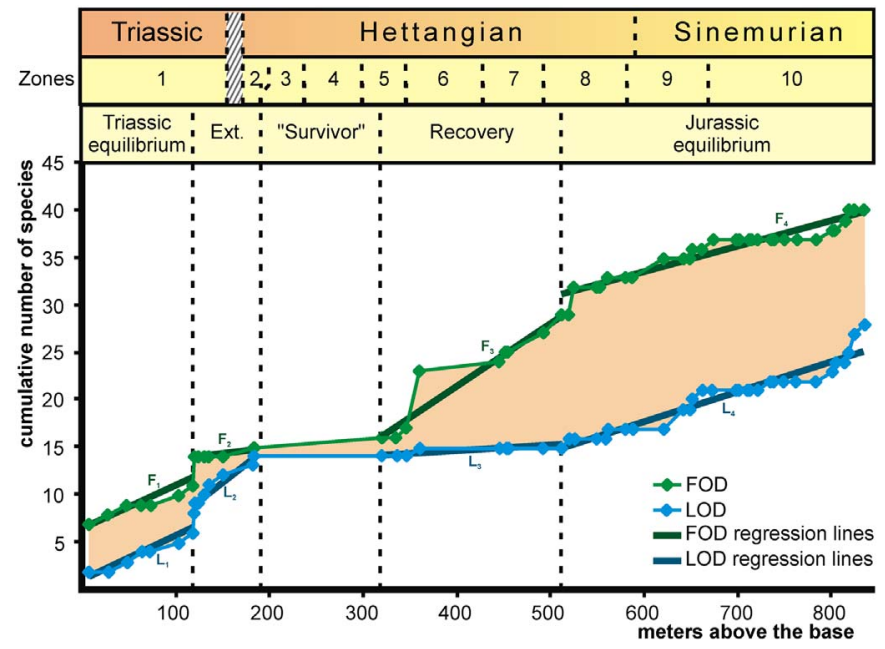

Fig. 6. Cumulative FODs and LODs against section thickness and their regression lines $\left(\mathrm{F}_{1}\right.$ to $\mathrm{F}_{4}$ and $\mathrm{L}_{1}$ to $\mathrm{L}_{4}$ respectively). Shaded area represents changes in diversity through time. Key to biozones: (1) Marshi-Crickmayi; (2) Psiloceras tilmanni; (3) Psiloceras primocostatum; (4) Psiloceras rectocostatum; (5) Kammerkarites bayoensis; (6) Discamphiceras reissi; (7) Sunrisites peruvianus; (8) Badouxia canadensis; (9) "Vermiceras"; (10) CoronicerasArnioceras.

the edge effect (see Section 4.1). When ex situ samples are included, diversity seems closer to that seen for the Hettangian-Sinemurian.

Bivalve diversity curve clearly shows a major diversity drop at the end-Triassic (finishing in the lowermost Hettangian) followed by a gap in the bivalve fossil record, roughly encompassing the Psiloceras primocostatum to $P$. rectocostatum Zones ( $\approx$ Planorbis Z). After that, diversity starts to rise in the Kammerkarites bayoensis ( $\approx$ early Liasicus) Zone followed by an increase peak in the Discamphiceras reissi ( $\approx$ late Liasicus) Zone. All these major changes in diversity can also be noticed from the instantaneous rates (Fig. 5).

Also probably due to the edge effect, diversity drop at the endTriassic may appear more gradual than it might have been. Interestingly, diversity rise during the Hettangian is sharper than the extinction. This is most likely a taphonomic bias: the $360 \mathrm{~m}$ sample comes from a relatively rich fossiliferous level. When longterm trends of origination and extinction are calculated (Fig. 6) this sample can be clearly seen as an outlier in the origination regression line, and the extinction phase appears much shorter than the total recovery phase.

When the cumulative FODs and LODs are plotted against section thickness, the difference between both curves represents the diversity changes through time (shaded area in Fig. 6). Four main phases were identified and characterized by their regression lines (see also Table 1): a first one (Triassic equilibrium phase) of almost parallel regression lines with relatively high rates $(0.044$ species/m for origination and 0.047 species/m for extinction); a second one (extinction phase) with high extinction rates $(0.077$ species $/ \mathrm{m})$ and low origination rates $(0.011$ species $/ \mathrm{m})$; a third one (recovery phase) of high origination rates $(0.066$ species $/ \mathrm{m}$ ) and almost null extinction rates $(0.006$ species $/ \mathrm{m})$; and a fourth one (Jurassic equilibrium phase) of almost parallel regression lines, with moderate rates $(0.027$ species $/ \mathrm{m}$ for origination and 0.032 species/m for extinction). The extinction and recovery phases are separated by a gap of about $135 \mathrm{~m}$ with almost no identifiable benthonic invertebrates, although ammonites are present and a few beds with shell hash indicate the presence of shelly fauna. The only bivalve species which spans this gap in the region, according to its records in the section just before and after it, is the pectinid Praechlamys cf. valoniensis, which is then the single detected bivalve survivor through the $\mathrm{Tr} / \mathrm{J}$ crisis. Though not considered as a phase per se (since there are no data to analyze or characterize it) the gap between extinction and recovery will be here referred to as "survivor phase" in figures and tables.

Regarding systematic representation of high rank categories, the 
Table 1

Extension and characterization of the recognized phases at the Alumbre/Malo Triassic/Jurassic section.

\begin{tabular}{|c|c|c|c|c|c|c|c|c|c|}
\hline \multirow[t]{2}{*}{ Recognized phases } & \multirow[t]{2}{*}{$\mathrm{m}$ above base } & \multirow[t]{2}{*}{ Time involved (aprox. Zones, see Fig. 4 for detail) } & \multirow[t]{2}{*}{ Estimated time $(\mathrm{kyr})^{\mathrm{a}}$} & & \multicolumn{2}{|c|}{ Estimated rates } & \multicolumn{3}{|c|}{ Regression } \\
\hline & & & & & Species/m & Species/100 kyr & $\mathrm{R}^{2}$ & $\mathrm{~N}$ & $\mathrm{p}$ \\
\hline \multirow[t]{2}{*}{ Triassic equilibrium } & 7 to 119 & Marshi-Crickmayi to P. tilmanni & 560 & FOD & 0.044 & 0.89 & 0.764 & 9 & 0.002 \\
\hline & & & & LOD & 0.047 & 0.93 & 0.876 & & $<0.001$ \\
\hline \multirow[t]{2}{*}{ Extinction } & 119 to 184 & & 325 & FOD & 0.011 & 0.23 & 0.524 & 9 & 0.027 \\
\hline & & & & LOD & 0.077 & 1.54 & 0.932 & & $<0.001$ \\
\hline "Survivor" & 184 to 319 & P. primocostatum to $P$. rectocostatum & 675 & & & & & & \\
\hline \multirow[t]{2}{*}{ Recovery } & 319 to 512 & K. bayoensis to $S$. peruvianus & 965 & FOD & 0.066 & 1.33 & 0.911 & 10 & $<0.001$ \\
\hline & & & & LOD & 0.006 & 0.12 & 0.716 & & 0.002 \\
\hline \multirow[t]{2}{*}{ Jurassic equilibrium } & 512 to 834 & B. canadensis to Coroniceras-Arnioceras & 1610 & FOD & 0.027 & 0.55 & 0.908 & 32 & $<0.001$ \\
\hline & & & & LOD & 0.032 & 0.64 & 0.927 & & $<0.001$ \\
\hline
\end{tabular}

${ }^{\text {a }}$ Estimated time in kyr is included merely for rough comparative reference, since it was based on average sedimentation rates.

Triassic shows a diverse pattern, with the 17 identifiable species recovered belonging to 13 superfamilies and 10 orders. During the recovery phase the orders Limida and Pectinida (either pectinoids or monotoids) seem to dominate, while pholadomyoids, pinnoids, crassatelloids and ostreoids were represented by a single species each. High rank taxa are more equally represented during the Jurassic equilibrium phase; the order Pectinida is still the most diverse, Limida is represented by only one species by the end of the span; and many other orders are again recorded in the basin.

\subsection{Palaeoecologic diversity trends}

Bivalve palaeoecologic diversity shows some peculiarities. The five main autoecologic categories are present throughout most of the section (Fig. 7), though epifaunal free-lying and semi-infaunal attached bivalves were not recorded from Triassic outcrops. Considering the Triassic sampling as a whole (including the ex-situ samples), infaunal habits seem to dominate over epifaunal ones. Nevertheless, when analyzing the stratigraphic distribution, epifaunal habits seem to slightly surpass infaunal ones during the Triassic equilibrium phase (Fig. 7). This trend is reverted only during a short interval within the extinction phase; considering the potential bias on this phase and the scarcity of data, no major significance can be given to this pattern. Associated fauna includes brachiopods (free-lying and pedunculate), gastropods, a coral colony and diverse cephalopods (ammonoids,

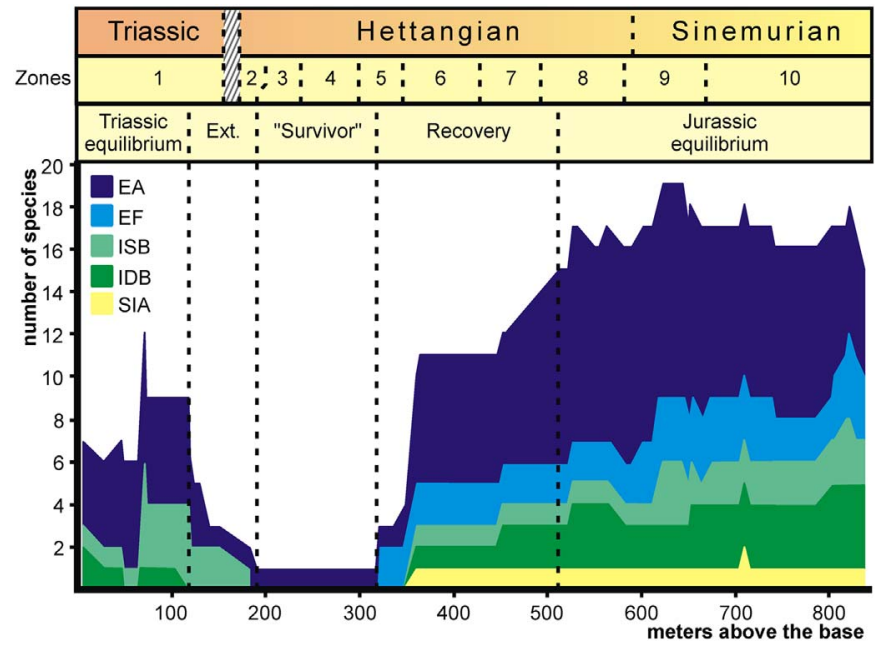

Fig. 7. Ecologic diversity against section thickness. EA: epifaunal attached, ISB: infaunal shallow burrowers, IDB: infaunal deep burrowers, EF: epifaunal free-lying, SIA: semiinfaunal attached. Key to biozones: (1) Marshi-Crickmayi; (2) Psiloceras tilmanni; (3) Psiloceras primocostatum; (4) Psiloceras rectocostatum; (5) Kammerkarites bayoensis; (6) Discamphiceras reissi; (7) Sunrisites peruvianus; (8) Badouxia canadensis; (9) "Vermiceras"; (10) Coroniceras-Arnioceras. nautiloids, coleoids).

Two identifiable taxa surpass the Triassic/Jurassic boundary: Neoschizodus? sp. (its last record in the basin being close to the base of the Hettangian) and the long lasting species Praechlamys cf. valoniensis. Sphaeriola? sp. is represented by a single record in the lowermost Hettangian. The last record of Neoschizodus? sp. and Sphaeriola? sp. in the lowermost Hettangian suggests that in the basin the extinction phase culminated at this stage. The "survivor phase" (184-319 m), encompassing the Psiloceras primocostatum and P. rectocostatum zones $(\approx$ Planorbis), yielded only unidentifiable shell debris (besides ammonites).

The recovery phase (319-512 $\mathrm{m}$ ) shows an increasing trend of absolute diversity, though with a high peak at the beginning $(360 \mathrm{~m})$. At this point all autoecologic categories of bivalves are represented, though three of them only by one species and other by two (Fig. 7). Nine of fifteen species (60\%) are epifaunal attached (all epibyssate), and this ecological category together with the infaunal deep burrower are the only two increasing in diversity during this interval (Fig. 7). Associated fauna is represented by solitary corals, brachiopods, a possible scaphopod, gastropods, ammonites and crinoids.

The final Jurassic equilibrium stage shows a somewhat stable diversity, decreasing at the end most likely due to the edge effect. Twenty-nine species have been identified for the interval, though standing diversity never reached the twenty species. Although epifaunal attached bivalves are still dominant (12 species: 41\%), they decrease during this time lapse (by the end of the section there are only 5 species out of 15, Fig. 7). Infaunal shallow burrowers diversify a little (5 species: $17 \%$ ) though they do not reach the diversity levels seen during the Triassic and the maximum standing diversity observed is 3 species. Infaunal deep burrowers continue to diversify, as well as epifaunal free-lying bivalves (species of Entolium, Lywea, Kolymonectes). The associated fauna is still diverse, with mobile epifauna (gastropods, regular echinoids), nektonic and nekto-benthonic cephalopods (ammonoids and nautiloids) and solitary corals. No crinoids were found at this stage and curiously no brachiopods.

\section{Discussion}

\subsection{Diversity pattern}

The pattern of diversity variation can be clearly subdivided in four phases and a gap ("survivor phase", Figs. 5, 6 and 7). The parallel regression lines for FODs and LODs vs. thickness clearly point to times of relatively stable diversities (equilibrium phases). The steeper slopes for Triassic equilibrium phase might be related to the edge effect. Despite the diversity underestimation, the recognition of a Triassic equilibrium phase allows for the delimitation of a relatively short (about $325 \mathrm{kyr}$ ) extinction interval, probably overestimated due to edge effect. In comparison, and in spite of the sudden diversity increase given by the $360 \mathrm{~m}$ sample bin, recovery lasts at least three times longer (about 
$965 \mathrm{kyr}$ ) or even five times if we also consider the "survivor phase" (about $675 \mathrm{kyr}$ ). This datum is similar to that found in Great Britain, where after a fast extinction a relatively slower recovery (though within the Hettangian) was observed (Wignall and Bond, 2008). Though a "survivor phase" can be recognized in the data of Wignall and Bond (2008), it shows higher diversity than in the section analyzed on this paper. This suggests a particularly severe end-Triassic extinction in the Neuquén Basin, with only two of eighteen species surviving the boundary, and one of them disappearing shortly after. Nevertheless, the extinction proportion (about 89\%) is in accordance with other specieslevel analyses (McRoberts and Newton, 1995).

According to Hallam (1996) the bivalve diversification trend during the recovery seems to continue until the lowermost Sinemurian in Great Britain. On the other hand the known example from Tibet shows an almost instantaneous recovery instead (Hautmann et al., 2008), though data are not recorded on a section-thickness base in that case. Broad bivalve species diversity in the Tibetan section is similar to our data (14 taxa for the uppermost Triassic and 24 for the lowermost Jurassic), but extinction proportion is much lower (57\%). All this suggests a general diversity pattern for our region more similar to Europe than to the Tibet examples, but this is just a limited statement and should not be read as a generalization, since these are the few known examples with enough comparable data.

\subsection{Ecologic pattern}

When comparing the life habit composition of known bivalve assemblages from this time interval, the high ecologic diversity in Tibet somewhat matches the early diversity in Argentinian section (Fig. 8), though in the South American basin species diversification probably lasted longer and the ecological categories represented, together with their relative abundance, differed markedly.

During the Triassic the proportion infaunal/epifaunal in the Neuquén Basin (Fig. 8) was slightly dominated by infaunal habits (53\% vs. 47\%). In the Southern Alps and Northwest Europe (McRoberts and Newton, 1995) proportions were similar (46\% infaunal/44\% epifaunal and $50 \%$ infaunal $/ 46 \%$ epifaunal respectively), while in the Northern Alps (McRoberts and Newton, 1995) and Tibet (Hautmann et al., 2008) epifaunal habits clearly dominated (32\% infaunal/60\% epifaunal and $36 \%$ infaunal $/ 64 \%$ epifaunal respectively). Given the low diversity recorded, the absence of semi-infaunal attached and free-lying habits might be a sampling bias (they are not very frequent and the Triassic portion of the section is highly affected by the edge effect). Otherwise, general proportions for the different life habits are similar to those found in Europe (McRoberts and Newton, 1995). Comparison is again restricted to the few regions with available data. Yet, dominance of infaunal habits coincides with global studies which show that infaunal bivalves surpassed in diversity epifaunal ones during the Late Triassic (Stanley, 1968; Ros and Echevarría, 2011). At the very end of this phase, three bivalve species are recorded: a) a very doubtful Neoschizodus? sp., with its record range ending there; b) Praechlamys cf. valoniensis (Defrance), which is clearly a survivor into Hettangian and even Sinemurian times; and c) one specimen of doubtful affinities, referred to Sphaeriola? sp.

After the end-Triassic extinction a long "survivor phase" was identified (135 m, about $675 \mathrm{kyr}$ ). During this phase, spanning the $P$. primocostatum to $P$. rectocostatum Zones ( $\approx$ Planorbis), no benthonic fauna was recorded. It might be considered as the survival interval (sensu Kauffman and Erwin, 1995; Kauffman and Harries, 1996), though it must be pointed out that no disaster or opportunistic species were detected in this section.

Despite the fact that only one species can be considered as survivor from the end-Triassic extinction event, the posterior scarcity of infaunal habits ( $38 \%$ vs $55 \%$ for epifaunal ones) suggests a similar pattern (favoring epifaunal life habits) to that found by McRoberts and Newton (1995) for Europe. Based on that pattern they suggested a drop in

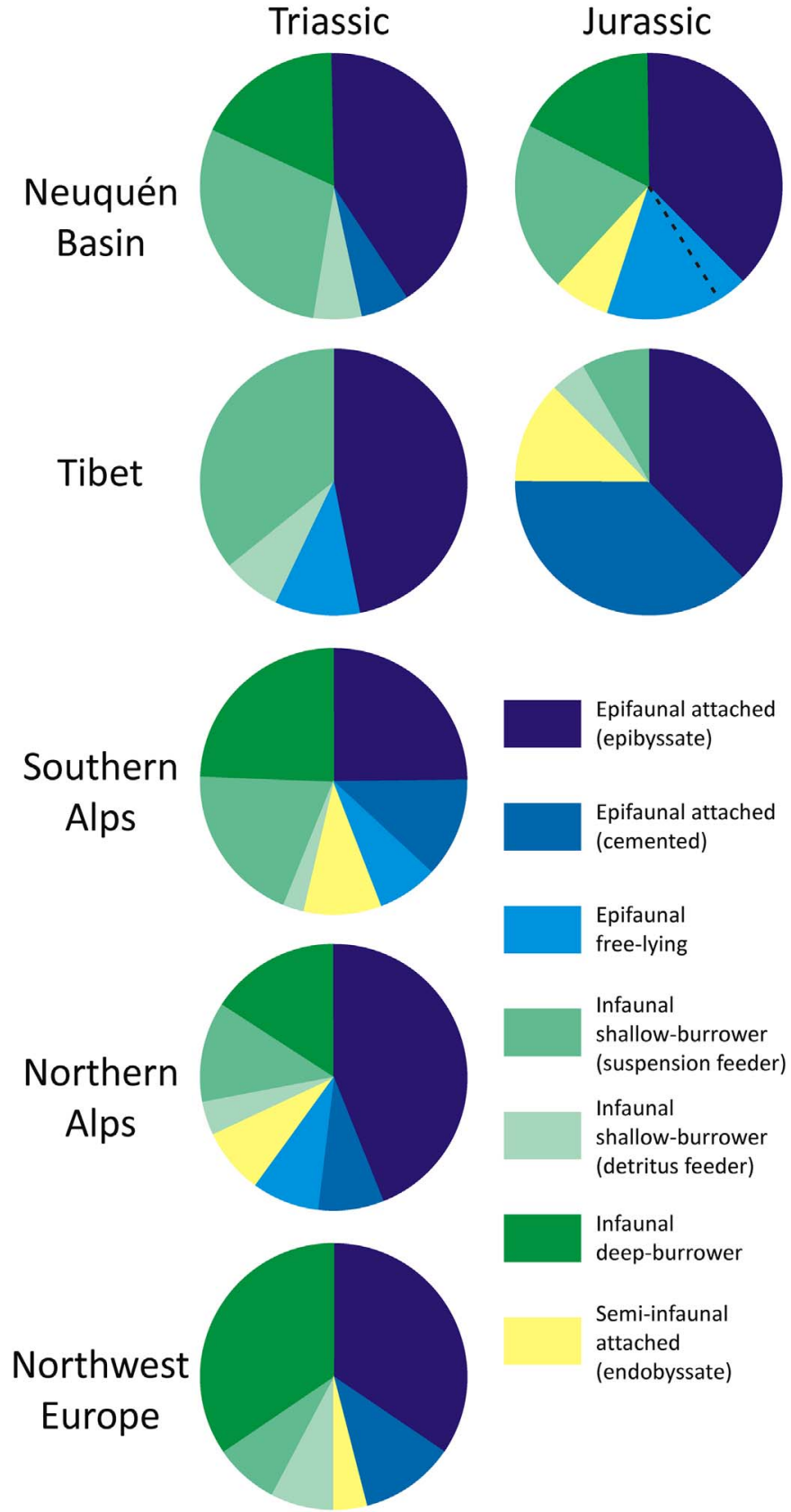

Fig. 8. Life habit percentage composition of some Triassic and earliest Jurassic bivalve assemblages. Tibetan data from Hautmann et al. (2008), European data from McRoberts and Newton (1995). Dotted line for the Jurassic of Neuquén Basin separates the taxon Gryphaea sp. (cemented at juvenile stages) from the remaining free-lying bivalves.

primary productivity as potential killing mechanism, since epifaunal bivalves are more efficient filter-feeders than infaunal ones. This pattern is even more evident in the Tibet section (13\% infaunal habits vs. $75 \%$ epifaunal ones in the Jurassic, Hautmann et al., 2008). One main difference is the strong abundance of bivalves with cementing habits in Tibet, which are almost absent in the Neuquén Basin for the Hettangian-Sinemurian (only juveniles of Gryphaea sp. can be regarded as cemented). This may simply reflect availability of suitable substrates in Tibet.

The recovery phase can be compared to the recovery interval (sensu Kauffman and Erwin, 1995; Kauffman and Harries, 1996), though neither Lilliput effect or beds dominated by opportunistic taxa could be recognized among bivalves from this region. The lowest Hettangian benthonic fauna recorded here after the long barren interval occurs 
within the $K$. bayoensis ( $\approx$ early Liasicus) Zone, has low bivalve diversity (2 epifaunal species), and is accompanied by few gastropod and isolated crinoid remains. This might be referred to a recovery stage 1 (sensu Twitchett, 2006), though the presence of crinoids would indicate some tiering differentiation. At $360 \mathrm{~m}$ (within the $D$. reissi ( $\approx$ late Liasicus Zone) there was a relatively rich fossiliferous shell bed with more diverse bivalves (the same 2 species recorded earlier plus at least 6 other species, including epifaunal and infaunal ecologic types); the first brachiopods (2 species) and solitary corals (Echevarría et al., 2017) recorded after the extinction appear also at this level. Tiering is fully recovered at this point (recovery stage 4 sensu Twitchett, 2006), since there are deep burrowers (pholadomyids, see Fig. 7), shallow burrowers (venerids), semi-infaunal molluscs [Pinna (Pinna) sp.], low epifaunal tier (limids, pectinids, brachiopods) and high epifaunal tier (crinoids, solitary corals?). Mobile epifauna (gastropods) and nektonic fauna are also represented. If we consider the sedimentary thickness between the beginning of the "survivor stage" (about $184 \mathrm{~m}$ ) and the $360 \mathrm{~m}$ sample, a time lapse of $880 \mathrm{kyr}$ can be estimated. This clearly points to a relatively fast ecologic recovery, though the ongoing increasing diversity suggests that this recovery had not yet been fulfilled at this point. It must be also pointed out that the epifaunal attached byssate life habit dominated the ecologic diversity, accounting for the preeminence of the Pectinida and Limida at this phase. Only Palmoxytoma cf. cygnipes and Antiquilima? sp. are characteristic of this phase, all other bivalves being long-lived elements common in the following Jurassic equilibrium phase.

During the Jurassic equilibrium phase, marked by the relatively stable diversity of 16 to 18 bivalve species, the change in proportions between the different ecologic categories was remarkable. The lack of two highly stenohaline groups like crinoids and particularly brachiopods (a widespread group in the Jurassic of the basin), is suggestive of some sort of salinity anomaly during this last phase. This agrees with the prograding interpretation within a deltaic environment made by Lanés (2005), though the presence of other stenohaline groups, like corals and ammonoids, indicates that any salinity variation should have been subtle. On the other hand, this potential environmental alteration is insufficient to explain the ecologic changes in bivalve associations, marked by the reduction of epifaunal habits and slight diversification of infaunal ones (especially deep burrowers), though epifaunal habits still dominate. Consequently, the ecological changes observed for bivalves during the Sinemurian in the analyzed section might result from ecologic successions in an environment more favorable for epifaunal habits, rather than the consequence of particular facial/environmental variations along it. This dominance (with both attached and free-lying habits well represented) is a common feature of Pliensbachian bivalve faunas in Neuquén Basin. At that stage the basin expanded extensively towards the south (Fig. 1), at the same time increasing its facial diversification, which may have favored epifaunal diversity.

\subsection{Taxonomic composition through time}

From the palaeobiogeographic point of view, there was a high proportion of endemism in Late Triassic faunas here studied, but the local diversity trends at species level for the recovery phase cannot be discussed because the systematic revision is still underway. Instead, it is possible to analyze the generic composition of the bivalve faunas through time. Genera were assigned to one of six evolutionary/biogeographic categories according to their known previous records of local and global occurrences: A) genera globally extinct in the Rhaetian, B) genera surviving the $\mathrm{Tr} / \mathrm{J}$ boundary in this section, C) genera surviving the $\mathrm{Tr} / \mathrm{J}$ boundary in the basin but not recorded in the Jurassic of this particular section, D) genera known from the Triassic elsewhere but immigrant into de Neuquén basin in the Jurassic; E) genera originated in the Jurassic elsewhere and immigrant into the Neuquén basin; and F) genera originated in the Jurassic in the Andean region, i.e. regionally endemic genera (Table 2).
It is interesting to point out that at the generic level the numbers of taxa recorded in this section before and after the extinction are similar: 18 genera were recorded in the Triassic and 20 in Hettangian-lower Sinemurian.

From the 18 bivalve genera present in the upper Triassic of the studied section, only four became globally extinct before the end of the Triassic (A in Table 2): Palaeocardita, Septocardia, Cassianella, and Minetrigonia. Small doubtful specimens from the lowermost Jurassic were very doubtfully referred to Neoschizodus? sp. Three genera appeared in the Jurassic: Palmoxytoma, Ceratomya and Lywea (E and F in Table 2). All other genera are also known (here or elsewhere) to have persisted into the Jurassic. Of these, only five genera survived in the study area (B in Table 2); apart from the doubtful record of Neoschizodus? sp., three genera being represented after the extinction event by a different species (Pseudolimea, Otapiria and Pholadomya), whilst Praechlamys cf. valoniensis is the only species that spanned the boundary. Nevertheless, it is evident that some of the genera present in the Triassic of this section did survive elsewhere in the region, as they are known from upper Lower Jurassic beds of the Neuquén Basin (C in Table 2), these include Palaeoneilo, Asoella, Cultriopsis, Liostrea and $\mathrm{Ni}$ caniella.

Although known from the Triassic around the world, the following genera have not yet been recorded in Triassic beds of the Neuquén Basin, but are present in the early Jurassic, thus they may be regarded locally as lower Jurassic immigrants (D in Table 2): during the Hettangian Camptonectes, Entolium, Agerchlamys, Plagiostoma, and Kalentera are locally recorded. To these, Pinna, Eopecten, Antiquilima, Gryphaea and Pleuromya may be added, although they are known from upper Triassic of northern Chile (Hayami et al., 1977; Chong and Hillebrandt, 1985; Rubilar, 1998). There is also a small group of lower Sinemurian immigrants, which includes Inoperna, Kolymonectes, Frenguelliella and Prosogyrotrigonia. Lywea is the only genus originated in the Andean region during the early Jurassic ( $F$ in Table 2). All these genera (categories B to F) are ubiquitous elements of upper Lower Jurassic South American faunas.

\section{Conclusions}

Marine bivalve diversity patterns during and after the end-Triassic extinction event (from Rhaetian to Early Sinemurian) show four clear phases in the Neuquén Basin: Triassic equilibrium, extinction, recovery and Jurassic equilibrium. Each phase is characterized by the relative relationships between regression lines of cumulative FODs and LODs. After a barren interval with no benthonic fauna, spanning most of the Planorbis Zone, bivalve fauna recovery was relatively rapid, within the Middle and lowermost Late Hettangian ( $K$. bayoensis to $S$. peruvianus local ammonite Zones, equivalent to Liasicus to early Angulata Zones). The taxonomic composition analysis through time (at the generic level) suggests that the recovery was mainly triggered by immigration into the basin of widely distributed genera, and the origination of new taxa was restricted. Of the five main autoecologic categories (epifaunal attached, epifaunal free-lying, semi-infaunal attached, infaunal shallow burrower, and infaunal deep burrower), two (epifaunal free-lying and semi-infaunal attached) were not recorded from Triassic outcrops. Considering the Triassic samples as a whole, infaunal habits seem to dominate over epifaunal ones. At the recovery phase all autoecologic categories of bivalves are represented, being epifaunal attached the most diverse category. This new set of local data provides an important addition to the knowledge of Lower Jurassic biotic recovery in the Southern Hemisphere, and can be compared with information from other latitudes to contribute to future global analyses.

\section{Acknowledgments}

A.C. Riccardi (La Plata Museum) led the early field trips to the studied area, and he also provided the necessary biostratigraphical 
Table 2

Summary of data from the Alumbre/Malo section analyzed in this paper.

\begin{tabular}{|c|c|c|c|c|c|c|}
\hline \multirow[t]{2}{*}{ Genus } & \multirow[t]{2}{*}{ Species } & \multicolumn{2}{|c|}{ Range in section } & \multirow[t]{2}{*}{ Extinct. cat. $^{\mathrm{a}}$} & \multirow[t]{2}{*}{ Ecologic cat. $^{\mathrm{b}}$} & \multirow[t]{2}{*}{ Biogeography category at this age ${ }^{c}$} \\
\hline & & $\mathrm{m}$ above base & biozones & & & \\
\hline "Laternula" & sp. & 7 & Marshi-Crickmayi & $?$ & IDB & $?$ \\
\hline Solemya? & sp. & 7 to 47 & Marshi-Crickmayi & $\mathrm{C}$ ? & IDB & Tehys-Circumpacific \\
\hline Promytilus? & sp. & 7 to 63 & Marshi-Crickmayi & $\mathrm{C} ?$ & $\mathrm{EA}(\mathrm{B})$ & Bipolar? \\
\hline Asoella & campbellorum Damborenea & 7 to 130 & Marshi-Crickmayi & $\mathrm{C}$ & $\mathrm{EA}(\mathrm{B})$ & Tethys, Circumpacific, Austral \\
\hline \multirow[t]{2}{*}{ Pseudolimea } & riccardii Damborenea & 7 to 135 & Marshi-Crickmayi & B & $\mathrm{EA}(\mathrm{B})$ & Cosmopolitan \\
\hline & ? sp. & 492 to 800 & B. canadensis to Cor-Arnioc & & $\mathrm{EA}(\mathrm{B})$ & \\
\hline Neoschizodus? & sp. & 7 to 182 & Marshi-Crickmayi to tilmanni & $\mathrm{B} ?$ & ISB(S) & Cosmopolitan \\
\hline Cultriopsis? & sp. & 7 & Marshi-Crickmayi & $\mathrm{C}$ & $\mathrm{EA}(\mathrm{B})$ & Cosmopolitan \\
\hline Praechlamys & cf. valoniensis (Defrance) & 28 to 756 & Marshi-Crickmayi to Cor-Arnioc. & B & $\mathrm{EA}(\mathrm{B})$ & Cosmopolitan \\
\hline \multirow[t]{2}{*}{ Otapiria } & cf. dissimilis (S. Cox) & 47 to 120 & Marshi-Crickmayi & B & $\mathrm{EA}(\mathrm{B})$ & Circumpacific, Austral, Boreal \\
\hline & pacifica Covacevich \& Escobar & 492 to 661 & B. canadensis to Vermiceras & & $\mathrm{EA}(\mathrm{B})$ & \\
\hline Palaeocardita & cf. peruviana L. Cox & 65 to 119 & Marshi-Crickmayi & A & $\operatorname{ISB}(S)$ & Tethys, Circumpacific, Austral \\
\hline \multirow[t]{4}{*}{ Pholadomya } & cf. ambigua (J. Sowerby) & 67 to 103 & Marshi-Crickmayi & B & IDB & Cosmopolitan \\
\hline & cf. oretiensis Campbell \& G.Mackie & 451 to 834 & S. peruvianus to Cor-Arnioc & & IDB & \\
\hline & gr. voltzi Agassiz & 525 to 562 & B. canadensis & & IDB & \\
\hline & cf. decorata & 651 to 739 & Vermiceras to Cor-Arnioc & & IDB & \\
\hline Septocardia & peruviana? (L. Cox) & 72 to 150 & Marshi-Crickmayi & A & $\operatorname{ISB}(S)$ & Tethys, Circumpacific, Austral \\
\hline Cassianella & cf. peruana Körner & 72 & Marshi-Crickmayi & A & $\mathrm{EA}(\mathrm{B})$ & Cosmopolitan \\
\hline Minetrigonia? & multicostata (Körner) & 72 & Marshi-Crickmayi & A & ISB(S) & Circumpacific, Austral, Boreal \\
\hline Nicaniella & cf. incae (Jaworski) & 72 & Marshi-Crickmayi & $\mathrm{C}$ & ISB(S) & Eastern Tethys, Austral? \\
\hline Liostrea & sp. & 72 to 119 & Marshi-Crickmayi & $\mathrm{C}$ & EAC & Cosmopolitan \\
\hline Palaeoneilo & cf. elliptica (Goldfuss) & 118 & Marshi-Crickmayi & $\mathrm{C}$ & ISB(D) & Cosmopolitan \\
\hline Sphaeriola? & sp. & 184 & P. tilmanni & $\mathrm{C}$ & ISB(S) & Cosmopolitan \\
\hline Gryphaea & sp. & 320 to 735 & K. bayoensis to Cor-Arnioc & $\mathrm{D}$ & EAC & J Cosmopolitan \\
\hline \multirow[t]{2}{*}{ Entolium } & sp. & 320 to 824 & K. bayoensis to Cor-Arnioc & $\mathrm{D}$ & EL & Cosmopolitan \\
\hline & cf. lunare (Römer) & 600 to 824 & Vermiceras to Cor-Arnioc & & EL & \\
\hline \multirow[t]{2}{*}{ Plagiostoma } & sp. & 346 to 783 & D. reissi to Cor-Arnioceras & $\mathrm{D}$ & $\mathrm{EA}(\mathrm{B})$ & Trias:Tethys \& boreal; J: cosmopolitan \\
\hline & ? sp. & 525 to 803 & B. canadensis to Cor-Arnioc & & EA(B) & \\
\hline \multirow[t]{2}{*}{ Antiquilima } & sp. & 360 to 520 & D. reissi to $B$. canadensis & $\mathrm{D}$ & $\mathrm{EA}(\mathrm{B})$ & Cosmopolitan \\
\hline & succincta & 512 to 642 & B. canadensis-Vermiceras & & $\mathrm{EA}(\mathrm{B})$ & \\
\hline Palmoxytoma & cf. cygnipes (Young \& Bird) & 360 to 530 & D. reissi to B. canadensis & $\mathrm{E}$ & $\mathrm{EA}(\mathrm{B})$ & Cosmopolitan \\
\hline \multirow[t]{2}{*}{ Eopecten } & sp. & 360 to 783 & D. reissi to Cor-Arnioceras & $\mathrm{D}$ & $\mathrm{EA}(\mathrm{B})$ & Tethys, Circumpacific, Austral \\
\hline & cf. velatus (Goldfuss) & 560 to 834 & B. canadensis to Cor-Arnioc & & $\mathrm{EA}(\mathrm{B})$ & \\
\hline Pinna & sp. & 360 to 824 & D. reissi to Cor-Arnioceras & $\mathrm{D}$ & SIA & Cosmopolitan \\
\hline Pleuromya & sp. & 360 to 800 & D. reissi to Cor-Arnioceras & $\mathrm{D}$ & IDB & Cosmopolitan \\
\hline Camptonectes & cf. subulatus (Münster) & 364 to 818 & D. reissi to Cor-Arnioceras & $\mathrm{D}$ & $\mathrm{EA}(\mathrm{B})$ & Cosmopolitan \\
\hline Agerchlamys & sp. & 525 to 824 & B. canadensis to Cor-Arnioc & $\mathrm{D}$ & $\mathrm{EA}(\mathrm{B})$ & Circumpacific, bipolar \\
\hline Kalentera? & sp. & 621 & Vermiceras & $\mathrm{D}$ & ISB(S) & Circumpacific, bipolar \\
\hline Prosogyrotrigonia & tenuis Pérez et al. & 674 to 818 & Coroniceras-Arnioceras & $\mathrm{D}$ & ISB(S) & Tethys, Circumpacific \\
\hline Inoperna? & sp. & 707 & Coroniceras-Arnioceras & $\mathrm{D}$ & $\mathrm{EA}(\mathrm{B})$ & Tethys, Austral \\
\hline Ceratomya? & sp. & 763 to 800 & Coroniceras-Arnioceras & $\mathrm{E}$ & IDB & $?$ \\
\hline Lywea & unca (Philippi) & 783 to 834 & Coroniceras-Arnioceras & $\mathrm{F}$ & EL & Eastern Pacific \\
\hline Frenguelliella & cf. poultoni Leanza & 803 & Coroniceras-Arnioceras & $\mathrm{D}$ & ISB(S) & Circumpacific \\
\hline Kolymonectes & sp. & 818 & Coroniceras-Arnioceras & $\mathrm{D}$ & EL & Circumpacific, bipolar \\
\hline
\end{tabular}

a Extinction categories: A: genus globally extinct in the Rhaetian; B: genus surviving the T/J boundary in the Alumbre/Malo section; C: genus surviving the T/J boundary in the basin but

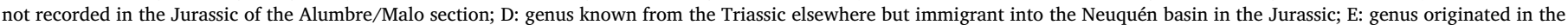
Jurassic elsewhere and immigrant into the Neuquén basin; F: genus originated in the Jurassic of the Andean region.

${ }^{\mathrm{b}}$ Ecologic categories: EA(B): epifaunal attached (byssate); EA(C): epifaunal attached (cemented); EL: epifaunal free lying; SIA: semi-infaunal attached ISB(S): infaunal shallow burrower (suspensivore); ISB(D): infaunal shallow burrower (detritivore); IDB: infaunal deep burrower.

c Biogeographic categories according to Ros-Franch et al. (2014).

frame based on ammonites and critically read an early version of this manuscript, he is gratefully acknowledged. We are very grateful to $\mathrm{M}$. Manceñido, who not only shared all the field work but contributed with interesting discussions on the subject. S. Lanés collected part of the material and contributed with her tectosedimentary knowledge of the region. We also thank two anonymous reviewers who provided helpful suggestions to improve the text. This research was supported mainly by several grants from CONICET (Consejo Nacional de Investigaciones Científicas y Técnicas, Argentina), most recent one PIP 112-20110101088; and partly by a Royal Society of New Zealand grant (ISA TB0806).

\section{References}

Aberhan, M., 1994. Early Jurassic Bivalvia of northern Chile. Part I. Subclasses Palaeotaxodonta, Pteriomorphia, and Isofilibranchia. Beringeria 13, 1-115. Aberhan, M., 2004. Early Jurassic Bivalvia of northern Chile. Part II. Subclass Anomalodesmata. Beringeria 34, 117-154.
Allasinaz, A., 1992. The Late Triassic-Hettangian bivalve turnover in Lombardy (southern Alps). Riv. Ital. Paleontol. Stratigr. 97, 431-454.

Bambach, R.K., Knoll, A.H., Wang, S.C., 2004. Origination, extinction, and mass depletions of marine diversity. Paleobiology 30, 522-542.

Barthel, K.W., 1958. Eine marine Faunula aus der mittleren Trias von Chile. N. Jb. Geol. Palaeont., Abh. 106, 352-382.

Beltan, L., Freneix, S., Janvier, P., López-Paulsen, O., 1987. La faune triassique de la Formation de Vitiacua dans la région de Villamontes (Dep. de Chuquisaca). N. Jb. Geol. Palaeont., Mh. 2, 99-115.

Benton, M.J., 1995. Diversification and extinction in the history of life. Science 268, 52-58.

Boit, B., 1966. Fauna de la facies Occidental del Noriano al Oeste de Colquijirca (Cerro de Pasco). In: Publicación del Museo de Historia Natural "Javier Prado", Universidad Nacional Mayor de San Marcos, serie C Geología. 11. pp. 1-15.

Cecioni, G., Westermann, G.E.G., 1968. The Triassic/Jurassic marine transition of coastal Central Chile. Pac. Geol. 1968, 41-75.

Chong, G., Hillebrandt, A.v., 1985. El Triásico preandino de Chile entre los $23^{\circ} 30^{\prime}$ y $26^{\circ}$ $00^{\prime}$ de lat. Sur. $4^{\circ}$ Congreso Geológico Chileno, Actas. 1. pp. 162-210.

Clémence, M.-E., Bartolini, A., Gardin, S., Paris, G., 2010. Early Hettangian benthicplanktonic coupling at Doniford (SW England). Palaeoenvironmental implications for the aftermath of the end-Triassic crisis. Palaeogeogr. Palaeoclimatol. Palaeoecol. 295, 102-115. 
Cooper, P., 1989. Enigmas in Phanerozoic reef development. Mem. Assoc. Australas. Palaeont. 8, 371-385.

Covacevich, V., Pérez, E., Escobar, F., 1991. Presencia del género Kalentera Marwick, 1953 (Mollusca, Bivalvia) en el Sinemuriano del Sur de Taltal, Chile. In: Actas 6 Congreso Geológico Chileno (Santiago). 1. pp. 68-71.

Cox, L.R., 1949. Moluscos del Triásico superior del Perú. Bol. Inst. Geol. Perú 12, 1-50.

Damborenea, S.E., 1987a. Early Jurassic Bivalvia of Argentina. Part I: stratigraphical introduction and superfamilies Nuculanacea, Arcacea, Mytilacea and Pinnacea. Palaeontogr. A 99, 23-111.

Damborenea, S.E., 1987b. Early Jurassic Bivalvia of Argentina. Part II: superfamilies Pteriacea, Buchiacea and part of Pectinacea. Palaeontogr. A 99, 113-216.

Damborenea, S.E., 1993. Early Jurassic South American pectinaceans and circum-Pacific palaeobiogeography. Palaeogeogr. Palaeoclimatol. Palaeoecol. 100, 109-123.

Damborenea, S.E., 1998. The bipolar bivalve Kolymonectes in South America and the diversity of Propeamussiidae in Mesozoic times. In: Johnston, P., Haggart, J.W. (Eds.), Bivalves: An Eon of Evolution - Paleobiological Studies Honoring Norman D. Newell. University of Calgary Press, Calgary, pp. 143-155.

Damborenea, S.E., 2002. Early Jurassic bivalves from Argentina. Part 3: superfamilies Monotoidea, Pectinoidea, Plicatuloidea and Dimyoidea. Palaeontogr. A 265, 1-119.

Damborenea, S.E., 2004. Early Jurassic Kalentera (Bivalvia) from Argentina and its palaeobiogeograhical significance. Ameghiniana 41, 185-198.

Damborenea, S.E., Lanés, S., 2007. Early Jurassic shell beds from marginal marine environments in southern Mendoza, Argentina. Palaeogeogr. Palaeoclimatol. Palaeoecol. 250, 68-88.

Damborenea, S.E., Manceñido, M.O., 2005. Biofacies analysis of Hettangian-Sinemurian bivalve/brachiopod associations from the Neuquén Basin (Argentina). Geol. Acta 3, 163-178.

Damborenea, S.E., Manceñido, M.O., 2012. Late Triassic bivalves and brachiopods from southern Mendoza, Argentina. Rev. Paléobiol. 11, 317-344.

Damborenea, S.E., Riccardi, A.C., Manceñido, M.O., Campbell, H.J., 2009. La significación de las faunas de invertebrados marinos del Triásico Superior de Sudamérica meridional. 12 Congreso Geológico Chileno (Santiago). Actas S5 (19) (3 pp).

Echevarría, J., Hodges, M.S., Damborenea, S.E., Stanley, G.D., Manceñido, M.O., 2017. Recovery of scleractinian morphologic diversity during the Early Jurassic in Mendoza Province, Argentina. Ameghiniana 54, 70-82.

Escobar, F., 1980. Paleontología y bioestratigrafía del Triásico superior y Jurásico inferior en el área de Curepto. Provincia de Talca. Bol. Inst. Inv. Geol. - Chile 35, 46-48.

Fang, Z., Boucot, A., Covacevich, V., Hervé, F., 1998. Discovery of late Triassic fossils in the Chonos Metamorphic Complex, southern Chile. Rev. Geol. Chile 25, 165-173.

Foote, M., 2000. Origination and extinction components of taxonomic diversity: general problems. Paleobiology 26, 74-102 Suppl. to No. 4).

Fuenzalida Villegas, H., 1937. Las capas de Los Molles. Bol. Mus. Nac. Hist. Nat. (Chile) $16,66-98$.

Geyer, O.F., 1973. Das präkretazische Mesozoikum von Kolumbien. Geol. Jahrb. B.B. 5, $1-155$.

Geyer, O.F., 1979. Ammoniten aus dem tiefen Unterjura von Nord-Peru. Paläont. Z. 53, 198-213.

Giambiagi, L., Bechis, F., Lanés, S., Tunik, M., García, V., Suriano, J., Mescua, J., 2008. Formación y evolución Triásico-Jurásica del depocentro Atuel, Cuenca Neuquina, Provincia de Mendoza. Rev. Asoc. Geol. Argent. 63, 520-533.

Guex, J., Bartolini, A., Atudorei, V., Taylor, D., 2004. High-resolution ammonite and carbon isotope stratigraphy across the Triassic-Jurassic boundary at New York Canyon (Nevada). Earth Planet. Sci. Lett. 225, 29-41.

Guex, J., Schoene, B., Bartolini, A., Spangenberg, J., Schaltegger, U., O"Dogherty, L., Taylor, D., Bucher, H., Atudorei, V., 2012. Geochronological constraints on post-extinction recovery of the ammonoids and carbon cycle perturbations during the Early Jurassic. Palaeogeogr. Palaeoclimatol. Palaeoecol. 346-347, 1-11.

Gutiérrez, F., 1979. Nuevos antecedentes sobre Monotis en Chile central. In: Actas $2^{\circ}$ Congr. Geol. Chileno. 3. pp. H63-H76.

Hallam, A., 1981. The end-Triassic bivalve extinction event. Palaeogeogr. Palaeoclimatol. Palaeoecol. 35, 1-44.

Hallam, A., 1987. Radiation and extinctions in relation to environmental change in the marine Lower Jurassic of northwest Europe. Paleobiology 13, 152-168.

Hallam, A., 1996. Recovery of the marine fauna in Europe after the end-Triassic and early Toarcian mass extinctions. In: Hart, M.B. (Ed.), Biotic Recovery from Mass Extinction Events. Geological Society Special Publication Vol. 102. pp. 231-236.

Hallam, A., Miller, A.I., 1988. Extinction and survival in the Bivalvia. In: Larwood, G.P. (Ed.), Extinction and Suvival in the Fossil Record. Systematics Association Special Volume Vol. 34. pp. 121-138.

Hallam, A., Wignall, P.B., 1997. Mass Extinctions and their Aftermath. Oxford University Press, Oxford (320 pp).

Hautmann, M., Stiller, F., Cai, H., Sha, J., 2008. Extinction-recovery pattern of levelbottom faunas across the Triassic-Jurassic boundary in Tibet: implications for potential killing mechanisms. PALAIOS 23, 711-718.

Hayami, I., Maeda, S., Ruiz Fuller, C., 1977. Some Late Triassic Bivalvia and Gastropoda from the Domeyko Range of northern Chile. Trans. Proc. Paleontol. Soc. Jpn 108, 202-221.

Hillebrandt, A. von, 1994. The Triassic-Jurassic boundary and Hettangian biostratigraphy in the area of the Utcubamba Valley (Northern Peru). Geobios Mém. Spec. 17, 297-307.

Hillebrandt, A. von, 2000a. Ammonite biostratigraphy of the Hettangian/Sinemurian boundary in South America. In: Hall, R.L., Smith, P.L. (Eds.), Advances in Jurassic Research 2000. GeoResearch Forum Vol. 6. pp. 105-118.

Hillebrandt, A. von, 2000b. Die Ammoniten-Fauna des südamerikanischen Hettangium (basaler Jura). Palaeontographica A, Teil I, 257, 85-189; Teil II, 258, 1-64; Teil III.
258. pp. 65-116.

International Commission on Stratigraphy, 2017. In: Cohen, K.M., Harper, D.A.T., Gibbard, P.L. (Eds.), The ICS International Chronostratigraphic Chart, . http://www. stratigraphy.org/ICSchart/ChronostratChart2017-02.pdf.

Jablonski, D., 1994. Extinctions in the fossil record. Philos. Trans. R. Soc. London, Ser. B 344, 11-17.

Jablonski, D., 2005. Mass extinctions and macroevolution. Paleobiology 31, 192-210.

Jaworski, E.G., 1922. Die marine Trias in Südamerika. N. Jb. Geol. Palaeont. Abh., B.B. 47, 93-200.

Johnson, L.A., Simms, M.J., 1989. The timing and cause of Late Triassic marine invertebrate extinctions: evidence from scallops and crinoids. In: Donovan, S.K. (Ed.), Mass Extinctions: Processes and Evidence. Columbia University Press, New York, pp. 174-194.

Kauffman, E.G., Erwin, D.H., 1995. Surviving mass extinctions. Geotimes 40, 14-17.

Kauffman, E.G., Harries, P.J., 1996. The importance of crisis progenitors in recovery from mass extinction. In: Hart, M.B. (Ed.), Biotic Recovery from Mass Extinction Events. Geological Society, London, Special Publications Vol. 102. pp. 15-39.

Kiessling, W., 2010. Reef expansion during the Triassic: spread of photosymbiosis balancing climatic cooling. Palaeogeogr. Palaeoclimatol. Palaeoecol. 290, 11-19.

Kiessling, W., Aberhan, M., Brenneis, B., Wagner, P.J., 2007. Extinction trajectories of benthic organisms across the Triassic/Jurassic boundary. Palaeogeogr. Palaeoclimatol. Palaeoecol. 244, 201-222.

Körner, K., 1937. Marine (Cassianer-Raibler) Trias am Nevado de Acrotambo (NordPeru). Palaeontogr. A 86, 145-237.

Lanés, S., 2005. Late Triassic to Early Jurassic sedimentation in northern Neuquén Basin, Argentina: Tectosedimentary evolution of the first transgression. Geol. Acta 3, 81-106.

Lanés, S., Giambiagi, L., Bechis, F., Tunik, M., 2008. Late Triassic - Early Jurassic successions of the Atuel depocenter: sequence stratigraphy and tectonic controls. Rev. Asoc. Geol. Argent. 63, 534-548.

Lathuilière, B., Marchal, D., 2009. Extinction, survival and recovery of corals from the Triassic to Middle Jurassic times. Terra Nova 21, 57-66.

Legarreta, L., Uliana, M.A., 2000. The Jurassic succession in west-central Argentina: stratal patterns, sequences and paleogeographic evolution. Palaeogeogr. Palaeoclimatol. Palaeoecol. 120, 303-330.

Maeda, S., Ishikawa, H., Kawabe, T., Morales-Serrano, L.G., 1983. Some Triassic Trigoniids from Peru. In: Bulletin of the Faculty of Education. 32. Chiba University, pp. 47-57.

Manceda, R., Figueroa, D., 1993. La inversión del rift Mesozoico en la faja fallada y plegada de Malargüe, Provincia de Mendoza. $12^{\circ}$ Congreso Geológico Argentino y $2^{\circ}$ Congreso de Exploración de Hidrocarburos. Actas 3, 219-232.

Mander, L., Twitchett, R.J., 2008. Quality of the Triassic-Jurassic bivalve fossil record in northwest Europe. Palaeontology 51, 1213-1223.

Mander, L., Twitchett, R.J., Benton, M.J., 2008. Palaeoecology of the Late Triassic extinction event in the SW UK. J. Geol. Soc. Lond. 165, 319-332.

McGhee, G.R., Sheehan, P.M., Bottjer, D.J., Droser, M.L., 2004. Ecological ranking of Phanerozoic biodiversity crises: ecological and taxonomic severities are decoupled. Palaeogeogr. Palaeoclimatol. Palaeoecol. 211, 289-297.

McGhee, G.R., Clapham, M.E., Sheehan, P.M., Bottjer, D.J., Droser, M.L., 2013. A new ecological-severity ranking of major Phanerozoic biodiversity crises. Palaeogeogr. Palaeoclimatol. Palaeoecol. 370, 260-270.

McRoberts, C.A., Newton, C.R., 1995. Selective extinction among end-Triassic European bivalves. Geology 23, 102-104.

McRoberts, C.A., Newton, C.R., Allasinaz, A., 1995. End-Triassic bivalve extinction: Lombardian Alps, Italy. Hist. Biol. 9, 297-317.

Moscoso, R., Covacevich, V., 1982. Las sedimentitas triásico-jurásicas al sur de Canto del Agua, Cordillera de la Costa, Región de Atacama, Chile: descripción de la formación Canto del Agua. In: Actas del $3^{\circ}$ Congreso Geológico Chileno. 3I. pp. 179-196.

Nicol, D., Allen, W.T., 1953. A new pelecypod genus from Upper Triassic strata in Peru? J. Wash. Acad. Sci. 43, 344-346.

Nielsen, S.N., 2005. The Triassic Santa Juana Formation at the lower Biobío River, south central Chile. J. S. Am. Earth Sci. 19, 547-562.

Pérez-Barría, L.P., 2004a. Estudio taxonómico de la fauna de invertebrados del Triásico del Biobío (VIII Región, Chile): una aproximación preliminar. Seminario de Título, Universidad de Concepción, Facultad de Ciencias Naturales y Oceanográficaspp. 1-87 (Unpublished).

Pérez-Barría, L.P., 2004b. Estudio taxonómico de la fauna de invertebrados del Triásico del Biobío (VIII Región, Chile): una aproximación preliminar. Suplemento Resúmenes Ameghiniana 41 (4), 18R.

Pérez-Barría, L.P., 2005. Revisión taxonómica de la fauna de moluscos del Triásico del Biobío (VIII Región, Chile). Nuevas evidencias sobre las relaciones paleobiogeográficas entre Chile y Nueva Zelandia. $19^{\circ}$ Congresso Brasileiro de Paleontologia e $6^{\circ}$ Congresso Latino-Americano de Paleontologia, CD-ROM/ Resumos/Taxonomia e Sistematica/pdf. Aracaju, Sergipe, Brasil.

Pérez, E., Aberhan, M., Reyes-Bianchi, R., Von Hillebrandt, A., 2008. Lower Jurassic Bivalvia of northern Chile. Part III. Order Trigonioida. Beringeria 39, 51-102.

Prinz, P., 1985. Stratigraphie und Ammonitenfauna der Pucará-Gruppe (ObertriasUnterjura) von Nord-Peru. Palaeontogr. A 188, 153-197.

Prinz, P., Hillebrandt, A. Von, 1994. Stratigraphy and ammonites of the North Peruvian Pucará Group. Palaeontogr. A 233, 33-42.

Quinzio, L.A., 1987. Stratigraphische Untersuchungen im Unterjura des Südteils der Provinz Antofagasta in Nord-Chile. Berl. Geowiss. Abh., Reihe A 87, 1-106.

Rangel, Z.C., 1978. Fósiles de Lircay-Uruto. Bol. Inst. Geol. Min. Perú, Ser. D. Est. Esp. 6, 1-35.

Raup, D.M., 1972. Taxonomic diversity during the Phanerozoic. Science 177, 1065-1071.

Raup, D.M., 1986. Biological extinction in earth history. Science 231, 1528-1533. 
Raup, D.M., Jablonski, D., 1993. Geography of end-Cretaceous marine bivalve extinctions. Science 260, 971-973.

Raup, D.M., Sepkoski Jr., J.J., 1982. Mass extinctions in the marine fossil record. Science 215, 1501-1503.

Raup, D.M., Sepkoski Jr., J.J., 1988. Testing for periodicity of extinction. Science 241, 94-96.

Riccardi, A.C., 2008a. The marine Jurassic of Argentina: a biostratigraphic framework. Episodes 31, 326-335.

Riccardi, A.C., 2008b. El Jurásico de Argentina y sus amonites. Rev. Asoc. Geol. Argent. 63, 625-643.

Riccardi, A.C., Iglesia Llanos, M.P., 1999. Primer hallazgo de amonites en el Triásico de la Argentina. Rev. Asoc. Geol. Argent. 54, 298-300.

Riccardi, A.C., Damborenea, S.E., Manceñido, M.O., Ballent, S., 1988. Hettangiano y Sinemuriano marinos en Argentina. In: Actas $5^{\circ}$ Congreso Geológico Chileno. 2. pp. C359-C373.

Riccardi, A.C., Damborenea, S.E., Manceñido, M.O., Ballent, S., 1991. Hettangian and Sinemurian (Lower Jurassic) biostratigraphy of Argentina. J. S. Am. Earth Sci. 4, 159-170.

Riccardi, A.C., Damborenea, S.E., Manceñido, M.O., Scasso, R., Lanés, S., Iglesia Llanos, M.P., 1997a. Primer registro de Triásico marino fosilífero de la Argentina. Rev. Asoc. Geol. Argent. 52, 228-234.

Riccardi, A.C., Scasso, R., Iglesia-Llanos, M.P., Lanés, S., Damborenea, S.E., Manceñido, M.O., 1997b. Hallazgo de Triásico marino fosilífero en la Argentina. In: VIII Congreso Geológico Chileno, Actas. vol. 1. pp. 578-579 Antofagasta, Chile.

Riccardi, A.C., Damborenea, S.E., Manceñido, M.O., Iglesia Llanos, M.P., 2004. The Triassic/Jurassic boundary in the Andes of Argentina. Riv. Ital. Paleontol. Stratigr. 110, 69-76.

Ros, S., 2009. Dinámica de la Paleodiversidad de los Bivalvos del Triásico y Jurásico Inferior. In: Tesis Doctoral. Servei de Publicacions de la Universitat de València 564 p.

Ros, S., Echevarría, J., 2011. Bivalves and evolutionary resilience: old skills and new strategies to recover from the $\mathrm{P} / \mathrm{T}$ and $\mathrm{T} / \mathrm{J}$ extinction events. Hist. Biol. 23, 411-429.

Ros, S., Echevarría, J., 2012. Ecological signature of the end-Triassic biotic crisis: what do bivalves have to say? Hist. Biol. 24, 489-503.

Ros, S., De Renzi, M., Damborenea, S.E., Marquez-Aliaga, A., 2011. Coping between crises: Early Triassic-Early Jurassic bivalve diversity dynamics. Palaeogeogr. Palaeoclimatol. Palaeoecol. 311, 184-199.

Ros-Franch, S., Márquez-Aliaga, A., Damborenea, S., 2014. Comprehensive database on Induan (Early Triassic) to Sinemurian (Early Jurassic) marine bivalve genera and their paleobiogeographic record. Paleontol. Contrib. 8, 1-219.

Rubilar, A., 1998. La superfamilia Ostreacea en Chile y su importancia cronoestratigráfica, paleogeográfica y paleoecológica (Triásico Superior-Jurásico). In: PhD Thesis. Universidad Nacional de La Plata 363 pp. (Unpublished).

Schaltegger, U., Guex, J., Bartolini, A., Schoene, B., Ovtcharova, M., 2008. Precise U-Pb age constraints for end-Triassic mass extinction, its correlation to volcanism and Hettangian post-extinction recovery. Earth Planet. Sci. Lett. 267, 266-275.

Sempere, T., Aguilera, E., Doubinger, J., Janvier, P., Lobo, J., Oller, J., Wenz, S., 1992. La Formation de Vitiacua (Permien Moyen à supérieur-Trias? inférieur, Bolivie du Sud): stratigraphie, palynologie et paléntologie. N. Jb. Geol. Paläont. (Abh.) 185, 239-253.

Signor III, P.W., Lipps, J.H., 1982. Sampling bias, gradual extinction patterns and catastrophes in the fossil record. In: Silver, L.T., Schultz, P.H. (Eds.), Geological Implications of Impacts of Large Asteroids and Comets on the Earth. Geol. Soc. Am. Spec. Publ Vol. 190. pp. 291-296.

Stanley, S.M., 1968. Post-Paleozoic adaptive radiation of infaunal bivalve molluscs - a consequence of mantle fusion and siphon formation. J. Paleontol. 42, 214-229.

Stanley, S.M., 1970. Relation of shell form to life habits of the Bivalvia (Mollusca). Mem. Geol. Soc. Am. 125, 1-296.

Stanley, G.D. (Ed.), 1994. Paleontology and stratigraphy of Triassic to Jurassic rocks in the Peruvian Andes. Palaeontogr. A 233, 1-208.

Steinmann, G., 1929. Geologie von Perú. C. Winters University, Heidelberg 448 pp.

Suárez-Riglos, M., Dalenz-Farjat, A., 1993. Pteriomorphia (Bivalvia) noriano de la Formación Vitiacua, del área de Villamontes (Tarija). Rev. Tec. YPFB 13-14, $155-160$.

Tanner, L.H., Lucas, S.G., Chapman, M.G., 2004. Assessing the record and causes of Late Triassic extinctions. Earth-Sci. Rev. 65, 103-139.

Thiele-Cartagena, R., 1967. El Triásico y Jurásico del departamento de Curepto en la provincia de Talca. 28. Publicaciones de la Universidad de Chile, Facultad de Ciencias Físicas y Matemáticas, Departamento de Geologíapp. 27-46.

Tilmann, N., 1917. Die Fauna des unteren und mittleren Lias in Nord- und Mittel-Peru. N. Jb. Geol. Palaeont., B.B. 41, 628-712.

Tunik, M.A., Lanés, S., Bechis, F., Giambiagi, L., 2008. Análisis petrográfico de las areniscas jurásicas tempranas en el depocentro Atuel de la Cuenca Neuquina. Rev. Asoc. Geol. Argent. 63, 714-727.

Twitchett, R.J., 2006. The palaeoclimatology, palaeoecology and palaeoenvironmental analysis of mass extinction events. Palaeogeogr. Palaeoclimatol. Palaeoecol. 232, 190-213.

Valentine, J.W., Jablonski, D., Krug, A.Z., Roy, K., 2008. Incumbency, diversity, and latitudinal gradients. Paleobiology 34, 169-178.

Warrington, G., Cope, J.C.W., Ivimey-Cook, H.C., 1994. St. Audrie's Bay, Somerset, England, a candidate global stratotype section and points for the base of the Jurassic System. Geol. Mag. 131, 191-200.

Westermann, G.E.G., 1970. Occurrence of Monotis subcircularis Gabb in central Chile and the dispersal of Monotis (Triassic Bivalvia). Pac. Geol. 2, 35-40.

Wignall, P.B., Bond, D.P.G., 2008. The end-Triassic and Early Toarcian mass extinction records in the British Isles. Proc. Geol. Assoc. 119, 73-84.

Wignall, P.B., Zonneveld, J.-P., Newton, R.J., Amor, K., Sephton, M.A., Hartley, S., 2007. The end Triassic mass extinction record of Williston Lake, British Columbia. Palaeogeogr. Palaeoclimatol. Palaeoecol. 253, 385-406. 